\title{
Scientific journals in Brazil and Spain: alternative publishing models
}

Rosângela Schwarz Rodrigues, Dra.

Professor at Programa de Pós-Graduaçao em Ciência da Informaçao

Universidade Federal de Santa Catarina, Brazil

rosangela@cin.ufsc.br

Ernest Abadal, Dr.

Full Professor at Facultat de Biblioteconomia i Documentació

Universitat de Barcelona, Spain

abadal@ub.edu

Rodrigues, R.; Abadal, E. (2014). "Scientific journals in Brazil and Spain: alternative publishing models". Journal of the Association for Information Science and Technology, Volume 65, Issue 10, pages 2145-2151, October 2014. (http://dx.doi.org/10.1002/asi.23115)

\begin{abstract}
This paper describes the situation of high-quality journals in Brazil and Spain, with emphasis on the distribution models used. It presents the general characteristics (age, type of publisher and theme) and analyses the distribution model by studying the type of format (print or digital), the type of access (open access or subscription) and the technology platform used. The 549 journals analyzed (249 in Brazil and 300 in Spain) are included in the 2011 lists of the WoS and Scopus databases. Data on each journal were collected directly from their websites between March and October 2012. Brazil has a fully open access distribution model $(97 \%)$ in which few journals require payment by authors thanks to cultural, financial, operational and technological support provided by public agencies. In Spain open access journals account for $55 \%$ of the total and have also received support from public agencies, although to a lesser extent. These results show that there are systems for the progress of open access in scientific journals other than the "author pays" system advocated by the Finch report for the United Kingdom.
\end{abstract}

\section{Introduction}

The Finch report (2012) has aroused controversy among academic specialists on open access. First, it deviates from the two roads advocated by the OA movement by failing to consider the role of repositories. Second, it bases the "gold road" solely on the "author pays" system, ignoring the possibility of institutional publishers paying the costs of open-access publishing, with the result that neither readers nor authors pay fees and the overall cost is low (Van Norden, 2013). 
Houghton and Swan (2013) agree that in a fully OA scientific communication system the net benefits of the gold road would outweigh those of the green road, but they consider that in the current transition phase, repositories are still the most economical and flexible way towards open access. Meanwhile, the latest recommendations by the Budapest Open Access Initiative (BOAI, 2012) still maintain the validity of the two roads and the infrastructure of repositories, stating that "Every institution of higher education should have an OA repository, participate in a consortium with a consortial OA repository, or arrange to outsource OA repository services".

The proposal of payment by authors as a basic element of the strategy has also raised controversy and doubts: Is the gold road possible in a single country? Would globalization of publishing increase or decrease in countries with a weak publishing structure? How can authors without research funding afford to pay for articles? The recommendations of the Budapest Open Access Initiative propose a reasonable cost model in the "author pays" system and even defend institutional funding to allow OA journals to waive fees".

Emerging countries do not have a consolidated publishing structure or a commercial publishing tradition. Southern European countries have few commercial publishers and more limited research grants than leading countries. Latin America countries are working to build and improve a scientific publication structure in the internationally recognized patterns using state-funded open access (Packer 2011).

The aim of this paper is to describe the situation of scientific journals in an emerging Latin American country and a Southern European country, Brazil and Spain, to describe their level of open access, and to make a preliminary analysis of how they have managed to achieve it.

\section{Background studies}

Brazil and Spain are the two Ibero-American countries with the greatest potential in the field of scholarly journals (Abadal, 2010; Rodrigues, Oliveira, 2012) and they are clearly dominant in this geographic area. The presence of Brazilian and Spanish journals in WoS and Scopus was fairly low until 2005 
(Rodríguez-Yunta, 2010, Packer 2011), but has since increased considerably due to the improvement of the titles and the increase in coverage of WoS and Scopus, which are competing for an expanding market.

Packer (2011) recorded the increase in Brazilian titles in WoS from 19 in 2005 to 71 in 2009 (and 128 in 2011, according to our data), attributing part of the growth to the SciELO collection, which has top researchers as editors, and universities and scientific associations as publishers. The same author describes a high level of decentralization of titles, with about 1.2 titles per publisher, in contrast with 19.4 in the Netherlands and 7.2 in England.

More than $90 \%$ of the Brazilian titles are published in open access by universities and associations (Rodrigues, Oliveira, 2012). Other influential factors are the use of the OJS platform, supported by the Brazilian Institute of Science and Technology (IBICT), and an active network of training initiatives and online help to editors and staff, mainly through libraries and portals and especially in universities (Garrido and Rodrigues, 2010). Mueller (2010) investigated the titles in SciELO in 2008 and identified 193 journals published mainly by scientific associations (47\%) and universities (35\%); in a high percentage of cases $(85 \%)$ the print versions were commercialized whereas the online version was freely available. Ten per cent of the journals charged the authors for publication, and this practice was concentrated in the areas of Medicine, Agriculture and Biological Science, with fees ranging from US\$60 to US $\$ 500$ per article.

Several studies have analysed the situation of journals in Spain. Urdin (2001) presented a description of the sector based on data of 2223 journals included in the Cindoc directory, ${ }^{i}$ and analysed the distribution of titles by subject, type of publisher, place of publication and format (digital or print). Osca et al. (2008) presented a similar study based on 3000 journals ${ }^{\mathrm{ii}}$ and analyzed aspects not included in the previous paper, especially national and international dissemination and visibility. The journals had a strong tradition, with $11 \%$ of the titles having being created in the period 1930-1970; almost three quarters of the titles were specialized in social and human sciences and they were written primarily in Spanish, with a few in English.

Other studies have taken a narrower approach. Bordons (2002) analyzed 30 Spanish journals that had a JCR impact factor, focusing on the type of 
publisher, the composition of the editorial boards (national or international), the impacts and the citation habits (self-citation, etc.). At that time there was a dominance of titles in Medicine, with $60 \%$ of the total, and commercial publishers accounted for $40 \%$ of the total (60\% in medicine). A study of Spanish university journals (Abadal \& Rius, 2008), representing a quarter of all titles, proposed seven lines of action to improve their dissemination and impact: digitization of content, inclusion in portals, open access publication, multilingual versions, dissemination of news, audience measurement, and inclusion in databases.

Rodríguez-Yunta and Giménez-Toledo (2013) highlighted the weaknesses of Spanish journals in the humanities and social sciences, a sector dominated by publishers related to the government and promoted by small groups with little impact, ineffective management and some degree of inbreeding. The strategies proposed to overcome this situation and increase quality and recognition are merging or co-publishing of journals.

Comparison of these studies is limited because of differences in the universe affecting the representativeness, in the quality of the journals analysed, and in the delimitation of subject categories.

\section{Objectives and methodology}

Brazil and Spain have different traditions and different histories in research and scientific communication but they currently have a similar number of journals indexed in WoS and Scopus and therefore considered of international quality standards. They also have a very significant percentage of open access titles. The question here is what strategies have been followed in each country to achieve this result in recent years.

The overall objective of this paper is to present the characteristics of the scientific journal sector and to analyze the distribution models that have been used. First, we present the characteristics of each country (age of journals, type of publisher and subject category). Then we analyse the distribution model, the formats used (print or digital), the type of access (open or subscription) and the technology platform used. 
The journals analysed here are the ones included in the WoS and Scopus lists of 2011. The titles were organized to avoid duplication and geographic errors were corrected. Data on each journal were collected directly from the websites of the journals between March and October 2012, and the results were subjected to a descriptive analysis. Since the two indexes use different subject categories, the option provided by Scopus was selected and we chose only the first one if the title was classified in several fields, as was the case for around $20 \%$ of the journals. All data were double-checked in February 2013, especially for availability on DOAJ lists, in order to compare the results with previous studies based on a similar universe.

\section{Results}

\subsection{General aspects}

For each country, we considered the date of creation of the journals, the type of publisher and the subject category.

Table 1. Year of creation of journals indexed in WoS and SCOPUS

\begin{tabular}{ccccccccccccc}
\hline & $1850-1989$ & $1990-1995$ & $1996-1999$ & \multicolumn{2}{c}{$2000-2005$} & $2006-2010$ & \multicolumn{2}{c}{ Total } \\
\hline \multirow{3}{*}{ Brazil } & $\mathbf{n}$ & $\%$ & $\mathbf{n}$ & $\%$ & $\mathbf{n}$ & $\%$ & $\mathbf{n}$ & $\%$ & $\mathbf{n}$ & $\%$ & $\mathbf{n}$ & $\%$ \\
Spain & 182 & 57.7 & 35 & 13.9 & 28 & 11.1 & 24 & 9.5 & 7 & 2.8 & 249 & 45 \\
Total & 240 & 43.7 & 77 & 14 & 62 & 11 & 66 & 12 & 21 & 3.8 & 549 & \\
\hline
\end{tabular}

Most titles are not new: around 58\% were created before 1995 (76\% of Brazilian journals and $71 \%$ of Spanish ones), when online publishing was not common. It can be deduced that well-established print journals migrated in mass to online publications. Whether or not the print alternative has been conserved is beyond the scope of this paper. In this aspect the two countries show a similar development, with slightly older titles in Brazil and newer ones in Spain. Computer Science is the only area with more titles created after 1996 than before. 
Table 2. Type of publishers of journals indexed in WoS and SCOPUS

\begin{tabular}{|c|c|c|c|c|c|c|c|c|c|c|c|c|c|c|c|c|}
\hline & 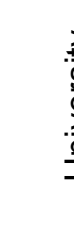 & & 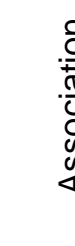 & & & 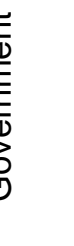 & & 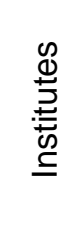 & & 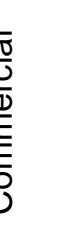 & & 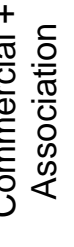 & & $\frac{\frac{\omega}{\omega}}{5}$ & \multicolumn{2}{|c|}{ Total } \\
\hline & $n$ & $\%$ & $n$ & $\%$ & $n$ & $\%$ & $n$ & $\%$ & $n$ & $\%$ & $\mathrm{n}$ & $\%$ & $n$ & $\%$ & $n$ & $\%$ \\
\hline Brazil & 118 & 47 & 100 & 40 & 8 & 3.2 & 12 & 4.8 & 2 & 0.8 & 4 & 1.6 & 5 & 2 & 249 & 45 \\
\hline Spain & 66 & 22 & 78 & 26 & 17 & 5.6 & 32 & 10 & 34 & 11 & 51 & 17 & 15 & 5 & 300 & 55 \\
\hline Total & 186 & 33 & 181 & 32 & 25 & 4.5 & 44 & 8 & 36 & 6.5 & 55 & 10 & 22 & 4 & 549 & 100 \\
\hline
\end{tabular}

* "Others" include association and university partnerships, government and commercial publishing partnerships, unidentified publishers, government and university partnerships, and other institutions.

In Brazil, universities and associations are responsible for $87 \%$ of the titles. These results are similar to those found by Mueller (2010) in a similar universe. In Spain, however, the distribution is shared more widely: it is led by associations (26\%), followed by universities (22\%), and partnerships between associations and commercial editors (17\%).

Commercial publishers in Spain, acting alone or in partnerships, especially with associations in the Medicine area, account for a large proportion of titles (28\%) if taken together. Another important point is the almost absence of commercial publishers in Brazil. 
Table 3. Subject category of journals indexed in WoS and SCOPUS

\begin{tabular}{|c|c|c|c|c|c|c|}
\hline \multirow[t]{2}{*}{ Subject category } & \multicolumn{2}{|c|}{ Brazil } & \multicolumn{2}{|c|}{ Spain } & \multicolumn{2}{|c|}{ Total } \\
\hline & $\mathbf{n}$ & $\%$ & $\mathbf{n}$ & $\%$ & $\mathbf{n}$ & $\%$ \\
\hline Agricultural and Biological Sciences & 52 & 21 & 23 & 8 & 75 & 14 \\
\hline Arts and Humanities & 14 & 6 & 39 & 13 & 53 & 10 \\
\hline Biochemistry, Genetics and Molecular Biology & 7 & 3 & 9 & 3 & & \\
\hline & & & & & 16 & 3 \\
\hline Business, Management and Accounting & 4 & 2 & 5 & 2 & 9 & 1.6 \\
\hline Chemical Engineering & 4 & 2 & 0 & 0 & 4 & 0.7 \\
\hline Chemistry & 4 & 2 & 1 & 0.5 & 5 & 1 \\
\hline Computer Science & 2 & 1 & 6 & 2 & 8 & 1.5 \\
\hline Decision Sciences & 1 & 0.5 & 1 & 0.5 & 2 & 0.3 \\
\hline Dentistry & 6 & 2 & 3 & 1 & 9 & 1.6 \\
\hline Earth and Planetary Sciences & 11 & 4 & 6 & 2 & 17 & 3 \\
\hline Economics, Econometrics and Finance & 7 & 3 & 8 & 3 & 15 & 2.7 \\
\hline Energy & - & & - & & - & \\
\hline Engineering & 7 & 3 & 6 & 2 & 13 & 2.3 \\
\hline Environmental Science & 8 & 3 & 3 & 1 & 11 & 2 \\
\hline Health Profe & 3 & 1 & 3 & 1 & 6 & 1 \\
\hline Immunology and Microbiology & 3 & 1 & 5 & 2 & 8 & 1.4 \\
\hline Materials Science & 3 & 1 & 1 & 0.5 & 4 & 0.7 \\
\hline Mathematics & 3 & 1 & 8 & 3 & 11 & 2 \\
\hline Medicine & 54 & 22 & 99 & 33 & 153 & 28 \\
\hline Multidisciplinary & 1 & 0.5 & 0 & & 1 & 0.2 \\
\hline Neuroscience & 1 & 0.5 & 1 & 0.5 & 2 & 0.3 \\
\hline Nursing & 6 & 2 & 3 & 1 & 9 & 1.6 \\
\hline Pharmacology, Toxicology and Pharmaceutics & 4 & 2 & 8 & 3 & 12 & 3.1 \\
\hline Physics and Astronomy & 2 & 1 & 1 & 0.5 & 3 & 0.5 \\
\hline Psychology & 12 & 5 & 15 & 5 & 27 & 5 \\
\hline Social Sciences & 25 & 10 & 45 & 15 & 70 & 13 \\
\hline Veterinary & 6 & 2 & 1 & 0.5 & 7 & 1.2 \\
\hline Total & 249 & 100 & 300 & 100 & 549 & \\
\hline
\end{tabular}

Brazil has two very prominent areas, Medicine and Agriculture, totalling more than $40 \%$ of the titles, followed at a great distance by Social Sciences (10\%) and Humanities (6\%). In Spain, Medicine stands out in first place (33\% of the total), followed by Social Sciences (15\%) and Humanities (13\%). Medicine and Social Sciences are therefore important in both countries, but Agriculture, Biology and Arts and Humanities show considerable differences. The areas with fewest titles are Energy, Multidisciplinary, Neuroscience and Decision Sciences.

\subsection{Distribution model}

To identify the characteristics of the different distribution models we considered the format, the system of access to content and the platform used. 
Table 4. Type of format of journals indexed in WoS and SCOPUS

\begin{tabular}{|c|c|c|c|c|c|}
\hline & \multicolumn{2}{|c|}{ Print only } & \multicolumn{2}{|c|}{$\begin{array}{c}\text { Full } \\
\text { text } \\
\text { online }\end{array}$} & \multirow[t]{2}{*}{ Total } \\
\hline & $n$ & $\%$ & $n$ & $\%$ & \\
\hline Brazil & 2 & 0.8 & 247 & 99 & 249 \\
\hline Spain & 22 & 7.3 & 280 & 93 & 300 \\
\hline Total & 24 & 4.3 & 527 & 96 & 549 \\
\hline
\end{tabular}

The print-only version is residual in both countries, especially in Brazil, confirming the massive adoption of the online format. However, the use of print versions is significantly higher in Spain $(7.3 \%)$ than in Brazil $(0.8 \%)$. This may be due to the existence of a percentage of titles in Arts and Humanities journals ( $28 \%$ of the total in Spain compared with $16 \%$ in Brazil), many of which still only publish in print.

The adoption of the online alternative for scientific journals was a subject of discussion in the early 2000s. Massive migration to the digital option has made it widely accepted in all areas and the journals still publishing in print-only format may adopt the digital format at any time.

Table 5. Type of access of journals indexed in WoS and SCOPUS

\begin{tabular}{lccccc}
\hline & \multicolumn{2}{c}{ Open access } & \multicolumn{2}{c}{ Subscription } & Total \\
\hline & $\mathbf{n}$ & $\%$ & $\mathbf{n}$ & $\%$ & \\
Brazil & 243 & 97 & 6 & 3 & 249 \\
Spain & 166 & 55 & 134 & 45 & 300 \\
Total & 409 & 75 & 140 & 25 & 549 \\
\hline
\end{tabular}

The greatest difference between the distribution models of Brazil and Spain is the importance of subscription titles in Spain and their almost complete absence in Brazil. An impressive 97\% of journals are open access in Brazil, compared with 55\% in Spain. In both countries, the "author pays" system is very uncommon: less than 10\% in Brazil (Mueller, 2010) and no cases in Spain. The journals receive funding mainly from government agencies and their own institutions. 
Other studies (Abadal et al, 2010; Miguel, Moya-Anegón \& ChinchillaRodriguez, 2012) have found different proportions of open access journals to the ones presented herein. These differences are due to the fact that they are based on data from DOAJ, the quintessential directory of open access journals, while our data were obtained directly by querying the websites of the journals. After comparing our list of titles with DOAJ, we were surprised at the large number of open access titles that were not listed: 99 in Spain (60\% of the total) and 29 in Brazil (12\% of the total).

The high level of digitalization means that a platform must be used to structure the issues and ensure that the title is available online full time. Table 6 , below, examines the alternatives used. It is important to note that some journals use more than one simultaneously, so the total for the platforms is greater than the number of titles.

Table 6. Web platforms used of journals indexed in WoS and SCOPUS

\begin{tabular}{lcccccc}
\hline & \multicolumn{2}{c}{ Brazil } & \multicolumn{2}{c}{ Spain } & \multicolumn{2}{c}{ Total } \\
\hline & $\mathbf{n}$ & $\%$ & $\mathbf{n}$ & $\%$ & $\mathbf{n}$ & $\%$ \\
In-house & 142 & 31 & 169 & 51 & 311 & $\mathbf{3 5}$ \\
SciELO & 190 & 78 & 27 & 8.2 & 217 & $\mathbf{2 5}$ \\
Redalyc & 49 & 10 & 1 & 0.3 & 49 & $\mathbf{6}$ \\
OJS & 67 & 15 & 62 & 19 & 129 & $\mathbf{1 5}$ \\
Elsevier & - & - & 48 & 15 & 48 & $\mathbf{6}$ \\
Springer & 1 & 0,22 & 11 & 3 & 12 & $\mathbf{1}$ \\
Others* & 4 & 0.8 & 9 & 3 & 13 & $\mathbf{1}$ \\
Total & 453 & & 327 & & 880 & \\
\hline
\end{tabular}

There is a significant level of overlap in the use of technology platforms. This phenomenon is more pronounced in Brazil (1.8 platforms per journal), especially in the journals indexed in SciELO, than in Spain (1.1 platforms per journal). The high number of in-house solutions shows the decentralization of the titles. A similar percentage of titles use OJS in Brazil (15\%) and Spain (19\%).

In Brazil the prevalence of SciELO, with $78 \%$ of the titles, shows once again the dominance of this meta-publisher, followed by in-house solutions 
(31\%) and OJS, and no commercial publisher platforms. In Spain there is no dominant meta-publisher: in-house solutions are dominant (50\%), followed by OJS (19\%), Elsevier (15\%), and at a distance by SciELO and Springer. Scielo began to operate in Spain with a pilot project in 2001 (Fraga et al, 2006) and from then on has obtained a respectable, but minority, presence far from its preeminence in Brazil. ${ }^{i i i}$ This may be due to the fact that Spanish publishers are better able to increase the visibility, metrics, etc. of the journals and Scielo has to compete with them.

\section{Discussion}

In view of the above data, two questions arise: How has it come about that in Brazil almost all of the highest-quality scientific journals are open access? And how is it that in Spain 55\% of journals are open access, a considerably higher figure than in neighbouring and culturally similar countries (Abadal et al, 2010, p. 130)?

In the case of Brazil, the explanation is that six key stakeholders have carried out a series of economic, political, and technological measures in addition to providing editorial training to promote scientific journals, along with the well-known work of Scielo. These stakeholders are the following:

a) SCIELO

SciELO started in 1998 with 10 journals. It currently has 274 titles in Brazil and is present in 11 countries, with a total of 1041 titles in July 2013. It has been a key player and has acted in several functions: as a platform with international standards and metrics, as an indexer that sets quality criteria to include and maintain the titles in this database, and as a provider of technological support (Packer, 2011).

b) The National Research and Technology Council (CNPq)

This government organization has an annual offer of grants to provide financial support to scientific journals. Its budget of about US $\$ 3$ million is distributed among about 200 titles. 
c) Universities

Universities are one of the most important types of publisher, with $47 \%$ of titles, offering structural, personal and technological support to their journals. They have provided space and security in the institutions' computer systems, library support to the publishers, and scholarships for students to help in editorial and standardization tasks. They have also assigned time for the professors working as editors, and they have created specific portals for using OJS to organize their journals (Rodrigues \& Fachin, 2010; Garrido \& Rodrigues, 2010).

d) CAPES Qualis

Qualis is a classification system of journals in each area of knowledge developed by the Coordenaçao de Aperfeiçoamento de Pessoal de Nivel Superior (CAPES), which has played a guiding role for journals. The rankings of graduate courses determining the amount of scholarships and grants they receive depend on the scores of the journals in which their authors publish. The position of the journals in the ranking influences the number and quality of the papers submitted to them (Barraviera, 2009; Machado \& Zaher, 2010).

e) The Brazilian Institute for Science and Information Technology (IBICT) This institute provides courses, research and political support for open access and for the OJS publishing platform.

f) The Brazilian Association of Scientific Editors (ABEC)

This association provides courses and organizes events on editorial issues for publishers.

Although the support to publishers in Brazil has not been centrally coordinated, it has successfully implemented the open access model in highquality journals. The prevalence of Scielo and the diversity of publishers and journals in open access without fees are consistent with the results presented by Solomon (2013).

In Spain, the action taken has focused on technology, training and advice. There has been hardly any direct financial support for journal publishing. The most important aspects are the following:

a) The legislative and regulatory framework

Spanish law and university regulations are currently quite favourable to open access: the 2011 Law on Science, Technology and Innovation includes an article on open access, and many Spanish Universities have approved self- 
archiving mandates (Abadal, Olle, Abad \& Melero, 2013). This framework has also helped change the awareness of publishers (especially those in the public sector) and authors.

b) FECYT (Spanish Foundation for Science and Technology)

This government agency has supported scientific publishing through a programme to improve the quality of journals, including training (courses, publication of materials, etc.) and also journal quality awards. The RECYT portal, based on OJS, provides technological support to 47 journals.

c) Universities and research Institutes

These two types of organization publish 39\% of the Spanish journals analysed and have provided funding and technological support to the journals to increase their quality and to distribute them through open access. The CBUC, a consortium of university libraries in Catalonia, has also provided technological support through the creation of RACO, a portal with 300 Catalan cultural and scientific journals (Anglada, 2008).

d) Journal evaluation indexes

Several indexes have been created in Spain to analyse the impact and readership of scientific journals, especially in the humanities and social sciences, which are not well represented in either WoS or Scopus. The Spanish journals thus have benchmarks to further enhance their quality. The most prominent indexes are CARHUS+, CIRC, IN-RECS and MIAR. ${ }^{\text {iv }}$

Although there is no comprehensive policy of support to scientific journals, this set of elements has allowed Spain to raise the percentage of open access journals to $55 \%$, a figure considerably higher than that of neighbouring countries. Publishers have played a major role in this process. They seem to have clearly seen the advantages of this model for disseminating academic content and have obtained funds to move to open access.

A key aspect to note in both countries is the absence of the "author pays" system, with few titles in Brazil and none in Spain. While this model is widespread in English-speaking countries and in the field of Health Sciences, it is practically non-existent in the journals analysed. This is a clear distinguishing feature, and shows another road towards open access based, as we have seen, on institutional funding by the government, universities and research centres. 


\section{Conclusions}

Despite the differences in size, economic growth and scientific research tradition, Brazil and Spain have a similar number of scientific journals included in the quality indexes and an insignificant number of "author pays" titles. This is a greater achievement in the case of Brazil, which started from a weaker scientific infrastructure in terms of number of research universities, research budget, number of qualified staff, etc.

There are no differences in the age of the journals, but there are great differences in the type of publisher, with more commercial publishers in Spain. The dominant subject categories are Medicine in Spain and Medicine and Agriculture in Brazil.

There are also great differences in the distribution model. The vast majority of Brazilian scientific journals (97\%) are available online in open access thanks to government and institutional grants and the support of the SciELO platform, which is used by $78 \%$ of the journals. This homogeneity gives the meta-publisher great power for standardization, dissemination and visibility. The situation in Spain is less defined. The open access model is adopted by a small majority of journals (55\%) but the lack of a powerful journal aggregator like SciELO leads to greater fragmentation. The support provided by FECYT and by the journals themselves is not comparable with the funding, technological support, and training provided by the Brazilian government.

Brazil and Spain have reached a similar result in terms of presence of journals in international impact indexes but they have taken different paths to reach this goal. Brazil has built its scientific research system recently thanks to public universities and governmental research programmes, State support for open access and the creation of a technological platform to support scientific journals have allowed the country to achieve a considerable level of international visibility in a short time.

Meanwhile, Spain has a significant presence of commercial publishers, although not a majority, and has a strong tradition of scientific journals directly related to university research. It has also achieved a significant increase in 
international visibility, but scientific publication has not had such solid support as Brazil.

We have identified two models of open access journal publishing: a wellconsolidated Brazilian model with over $90 \%$ of the titles in open access (Guédon, 2010; Rodrigues \& Oliveira, 2012), and a Spanish model with 55\% of the titles in open access.

Though neither Brazil nor Spain have used the "author pays" system, they have both achieved a high proportion of open access scientific journals. It is clear that alternatives to the "author pays" system are based on economic, technical, and political support for scientific journals -and for scientific communication in general- by governments, universities and associations. The extent of open access depends on the level and sustainability of this support.

Comparative studies can be useful to explore the diversity of scenarios in scientific publishing today, and also to identify benchmarks for planning open access policies. The results of the present study show the existence of affordable and effective ways to extend the $O A$ model without requiring payment by authors. We must therefore clarify the term "gold road", which is sometimes misunderstood and associated almost exclusively with the "author pays" business model. In this case the option "publisher pays", also known as "platinum access" (Crawford, 2011) is neglected. Suber (2012), who prefers the term "publications fees" instead of "author pays", also has a chapter discussing this question.

\section{Acknowledgments}

This study was funded by a fellowship from the Brazilian Coordination for the Improvement of Higher Education Personnel (CAPES) and the Spanish "Plan Nacional de I+D+l" CSO2011-29503-C02-01/SOCl. The authors would like to thank Patricia Neubert, Aline Oliveira, Luiza Gularte and Miguel Navas for their help in the data gathering and checking. 


\section{References}

Abadal, E., Ollé-Castellà, C., Abad-García, F., \& Melero, R. (2013). Políticas de acceso abierto a la ciencia en las universidades españolas. Revista Española de Documentación Científica, 36, 2, e007. Retrieved May 4, 2013, from http://dx.doi.org/10.3989/redc.2013.2.933

Abadal, E., \& Rius, L. (2008). Revistas científicas de las universidades españolas: acciones básicas para aumentar su difusión e impacto. Revista Española de Documentación Científica, 31, 2, 242-262. Retrieved May 4, 2013, from http://redc.revistas.csic.es/index.php/redc/article/view/427/439

Abadal, E. et al (2010). Open access in Spain. In Anglada, L. \& Abadal, E. (eds.), Open access in Southern European countries (pp. 101-115). Madrid: FECYT. Retrieved May 4, 2013, from

http://oaseminar.fecyt.es/Resources/Documentos/OAreport/OASouthEurope_07_Spain .pdf

Anglada, L., Reoyo, S., Cambras, J. \& Vega, R. (2008). Els dipòsits electrònics cooperatius de la Biblioteca Digital de Catalunya. BiD: textos universitaris de biblioteconomia i documentació, 20. Retrieved May 4, 2013, from http://bid.ub.edu/20angla1.htm

Barraviera, B. (2009). Editorial: the ABEC, research grant agencies, CAPES mandatory evaluations and how Brazilian journals can pay their bills. Brazilian Oral Research, 23, 4. Retrieved May 4, 2013, from http://dx.doi.org/10.1590/S1806-83242009000400001

BOAI (2012). Budapest Open Access Initiative: ten years on from the Budapest Open Access Initiative: setting the default to open. Retrieved May 4, 2013, from http://www.opensocietyfoundations.org/openaccess/boai-10-recommendations

Bordons, M., Felipe, A. \& Gómez, I. (2002). Revistas científicas españolas con factor de impacto en el año 2000. Revista Española de Documentación Científica, 25, 1, 4971. Retrieved May 4, 2013, from http://redc.revistas.csic.es/index.php/redc/article/view/86/147

Crawford, W. (2011). Open access: what you need to know now. Chicago: American Library Association.

Finch, J. (2012). Accessibility, sustainability, excellence: how to expand access to research publications. Retrieved May 4, 2013, from http://apo.org.au/sites/default/files/Finch-Group-report-FINAL-VERSION.pdf

Fraga-Medín, C., Bojo-Canales, C. \& Hernández-Villegas, S. (2006). Pasado, presente y futuro del proyecto Scielo en España. El profesional de la información, 15, 1, 23-28. Retrieved May 4, 2013, from http://www.elprofesionaldelainformacion.com/contenidos/2006/enero/4.pdf

Garrido, I. \& Rodrigues, R. (2010). Portais de periódicos científicos online: organização institucional das publicações. Perspectivas em Ciência da Informação, 15, 56-72.

Retrieved May 4, 2013, from http://portaldeperiodicos.eci.ufmg.br/index.php/pci/article/view/943 
Guédon, J-C. (2010). Acesso aberto e divisão entre ciência predominante e ciência periférica. In Ferreira, S.M.S.P., \& Targino, M. G., Acessibilidade e visibilidade de revistas científicas eletrônicas. São Paulo: SENAC; Cengage Learning.

Houghton, J. \& Swan, A. (2013). Planting the green seeds for a golden harvest: comments and clarifications on "Going for Gold". D-lib magazine, 19, 1-2. Retrieved May 4, 2013, from doi:10.1045/january2013-houghton

Machado, F.A. \& Zaher, H. (2010). Pitfalls of artificial grouping and stratification of scientific journals based on their impact factor: a case study in Brazilian zoology. Zoologia (Curitiba), 27, 4, 493-50. http://www.scielo.br/scielo.php?pid=S1984$46702010000400002 \&$ script=sci_arttext\&tlng=pt

Miguel, S., Moya-Anegón, F. de \& Chinchilla-Rodriguez, Z. (2011). Open access and Scopus: a new approach to scientific visibility from the standpoint of access. Journal of the American Society for Information Science and Technology, 62, 6, 1130-1145. Retrieved May 4, 2013, from http://eprints.rclis.org/16100/

Mueller, Suzana Pinheiro Machado. Produçao e financiamento de periódicos científicos de acesso aberto: um estudo na base SciELO. In: FUNARO, Vânia de Oliveira et al. (Org.). Dos processos tradicionais às perspectivas alternativas de comunicação. São Paulo: Ateliê Editorial, 2011.

Osca, J. et al. (2008). Difusión y factor de impacto nacional e internacional de las revistas científicas españolas. Anales de documentación, 11. Retrieved May 4, 2013, from http://revistas.um.es/analesdoc/article/view/24861

Packer, A. L. (2011). Os periódicos brasileiros e a comunicação da pesquisa nacional. Rev. USP, 89, 26-61. Retrieved May 4, 2013, from $<$ http://rusp.scielo.br/scielo.php?script=sci_arttext\&pid=S010399892011000200004\&lng=pt\&nrm=iso>

Rodrigues, R., \& Fachin, G. R. (2010). Portal de periódicos científicos: um trabalho multidisciplinar. Transinformação, 22, 33-45. Retrieved May 4, 2013, from http://periodicos.puc-campinas.edu.br/seer/index.php/transinfo/article/view/483

Rodrigues, R., \& Oliveira, A.B. (2012). Periódicos científicos na America Latina: títulos em acesso aberto indexados no ISI e Scopus. Perspectivas em Ciência da Informação, 17, 76-99. Retrieved May 4, 2013, from http://portaldeperiodicos.eci.ufmg.br/index.php/pci/index

Rodríguez-Yunta, L. (2010). Las revistas iberoamericanas en Web of Science y Scopus: visibilidad internacional e indicadores de calidad. In Memoria del VII Seminario Hispano-Mexicano de Investigación en Bibliotecología y Documentación, Ciudad de México, 7-9 de abril de 2010 (pp. 347-363). Retrieved May 4, 2013, from http://digital.csic.es/handle/10261/23811

Rodríguez-Yunta, L. \& Giménez-Toledo, E. (2013). Fusión, coedición o reestructuración de revistas científicas en humanidades y ciencias sociales. El profesional de la información, 22, 1, 36-45. Retrieved May 4, 2013, from http://dx.doi.org/10.3145/epi.2013.ene.05

Solomon, D. (2013). Types of open access publishers in Scopus. Publications 2013, 1, 1, 16-26. Retrieved June 4, 2013, from doi:10.3390/publications1010016. 
Suber, P. (2012). Open access. Massachussets: MIT Press. Retrieved June 4, 2013, from

http://mitpress.mit.edu/sites/default/files/titles/content/9780262517638_Open_Access_ PDF_Version.pdf

Urdín, C. (2001). La edición de revistas científicas en España. In La edición de revistas científicas. Guía de buenos usos (p. 11-16). Madrid: CINDOC. Retrieved May 4, 2013, from (http://hdl.handle.net/10261/4347) (http://digital.csic.es/bitstream/10261/4347/1/R21.pdf)

Van Norden, R. (2013). Open access: the true cost of science publishing. Nature, 495, 426-429. Retrieved July 28, 2013, from http://www.nature.com/news/open-access-thetrue-cost-of-science-publishing-1.12676

\section{Notes}

'The journal directories of Cindoc (http://bddoc.csic.es:8080/index.jsp) are divided into three separate areas, Science and Technology, Social Sciences and Humanities, and Biomedicine, and they contain a description of the journal titles published in Spain.

ii The total number of journals included is considerably higher than the number offered by the directories because some inactive titles are included.

\footnotetext{
iii There was an initial growth in titles but now the situation has stabilized at around 40 (27 of them considered in our text).

${ }^{\text {iv }}$ For more information about these indexes, see the following sites: Carhus+ (http://www10.gencat.cat/agaur_web/AppJava/english/a_info.jsp?contingut=carhus_2010), CIRC (http://epuc.cchs.csic.es/circ/), IN-RECS (http://ec3.ugr.es/in-recs/), MIAR (http://miar.ub.edu/).
} 